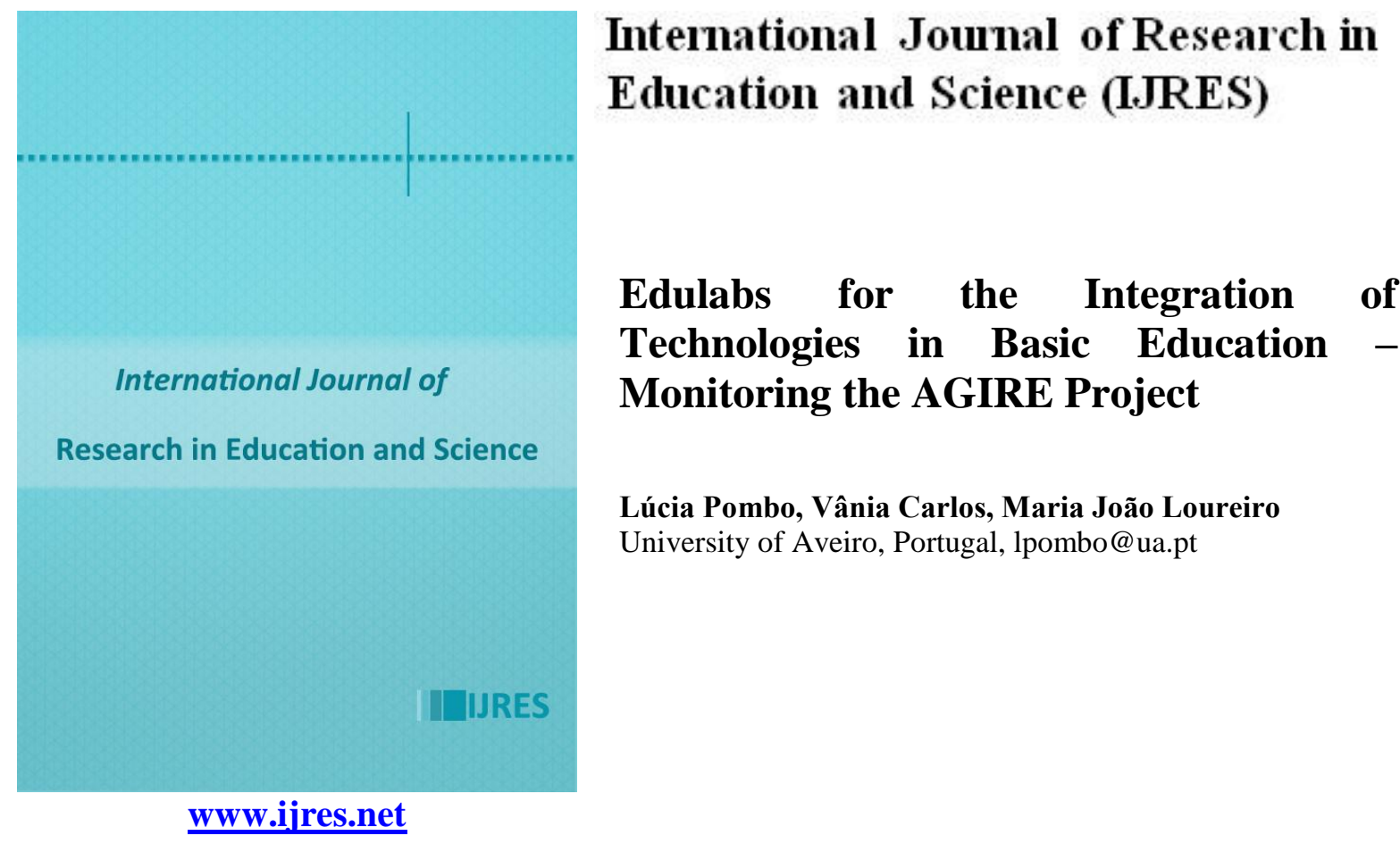

To cite this article:

Pombo, L., Carlos, V. \& Loureiro, M.J. (2016). Edulabs for the integration of technologies in Basic Education - monitoring the AGIRE project. International Journal of Research in Education and Science (IJRES), 2(1), 16-29.

This article may be used for research, teaching, and private study purposes.

Any substantial or systematic reproduction, redistribution, reselling, loan, sub-licensing, systematic supply, or distribution in any form to anyone is expressly forbidden.

Authors alone are responsible for the contents of their articles. The journal owns the copyright of the articles.

The publisher shall not be liable for any loss, actions, claims, proceedings, demand, or costs or damages whatsoever or howsoever caused arising directly or indirectly in connection with or arising out of the use of the research material. 


\title{
Edulabs for the Integration of Technologies in Basic Education - Monitoring the AGIRE Project
}

\author{
Lúcia Pombo*, Vânia Carlos, Maria João Loureiro \\ University of Aveiro, Portugal
}

\begin{abstract}
The AGIRE project is a partnership between the University of Aveiro, a consortium comprising 26 companies related to teaching and learning, and one School Grouping, with the financial support of QREN. The project is embedded into the Edulab concept (school laboratories with technological equipment, as tablets, laptops, whiteboards, and educational materials such as eBooks and learning platforms) to promote the adoption of innovative teaching practices. The project stems from identified contextual needs and aims to monitor the project implementation within an interventional perspective, concerning educational innovation with the use of digital technologies. The goal is to promote teachers' and students' digital literacy, by developing Teacher Training Courses (TTC) and taking advantage from the school technology environment on a pedagogical level. After attending a short-term (15 hours) technological TTC, a 64-hour TTC involving 13 teachers of Basic Education during the current school year is being conducted. The TTC, developed in a blended learning environment, follows the flipped classroom methodology comprising autonomous tasks for consulting multimedia resources at a distance and face-to-face sessions for discussion, reflection and collaborative work. This fits into a design-based methodology (Parker, 2011), allowing the analysis of the intervention outcomes and it's successively refinement towards a solution, following the phases: i) Analyze the problem; ii) Design and develop potential solutions; iii) Implement and evaluate; and iv) Reflect and report. A set of data collection instruments developed under this project allowed its monitoring, as well as the redefinition of the TTC and its previewed activities. For example, the questionnaire on the trainee teachers' digital literacy, the grid to monitor the strategies implemented in classrooms, as well as the autonomous work tasks allowed each teacher to position its practice at the level of technology integration and to raise his/her expectations towards the educational technologies.
\end{abstract}

Key words: Edulabs; ICT in Education; Teacher training; Collaborative learning; Flipped classroom

\section{Introduction}

As noted by Horta (2013), the introduction of computers in schools led to the need to prepare teachers for its use. Among the many studies developed in teacher training in Information and Communication Technologies (ICT) and its impact in their teaching practice stands out the importance of Lifelong Learning (LLL) and in service teacher training (Costa \& Garmston, 2015). Also, several studies point to extensive evidence of the importance of ICT in improving student learning, and it also appears that these benefits are dependent on the strategies and pedagogical practices used, that is, the way the teacher selects and organizes ICT resources (Cox, Webb, Abbott, Blakeley, Beauchamp \& Rhodes, 2004). Studies indicate therefore that the main training needs in this area are in the educational use of ICT, namely enabling teachers to be autonomous users of technology in their teaching practices and promoting the use of ICT with students (Monteiro \& Loureiro, 2009).

According to the literature the most favorable conditions for the integration of ICT by teachers in their teaching practice include: i) the creation of a training environment where teachers collaborate and reflect on the work that they can develop with ICT to promote powerful learning environments (Sipila, 2010; Horta, 2013); ii) the development of practical activities with ICT, planned and implemented in classroom with appropriate pedagogical practices, such as problem solving with the use of ICT (Yelland, 2006), and selecting meaningful methodologies such as collaborative work and flipped classroom (Bergmann, J. \& Sams, A., 2012); iii) using, during the teacher training course, the same technology and methodologies that later will serve teachers in their teaching practice, in classroom. It is also important to note the potential effect of promoting access to these resources on family context for strengthening school learning, reducing inequalities in the use of ICT and bringing school contexts to family (Silva \& Diogo, 2011; Paiva, 2006). The flipped classroom, consisting of the

\footnotetext{
* Corresponding Author: Lúcia Pombo,lpombo@ua.pt
} 
replacement of the traditional in-class lectures with videos/tutorials that students are expected to watch before class (and therefore, in class, the prepared students solve hands-on problems related to the videos/tutorials) (Day \& Foley, 2006), was specifically used in this project as a methodology for the evolution of quality of teaching scenarios and learning and for the improvement of school-family relationship.

This ongoing research, the AGIRE project, falls within the above mentioned context and follows the Edulabs concept that is presented in the following paragraphs. The project is promoted by the e-Xample consortium that comprises 26 companies related to teaching and learning, particularly Grupo Leya ${ }^{\circledR}$, JP-inspiring knowledge ${ }^{\circledR}$, b-bright $\AA$, Globaltronic $\AA$, PT Inovação $\AA$, among others. Being focused on creating experimental learning ecosystems, Edulabs are student classrooms technologically and didactically equipped to promote innovation in education. AGIRE is a collaboration project between the e-Xample consortium, the University of Aveiro and the School Grouping of Gafanha da Nazaré (Aveiro), focused in promoting the following main dimensions: i) digital literacy of the actors (students, teachers and parents); ii) teacher training on the integration of technologies in education; iii) innovation of educational practices; iv) community involvement - parents; and v) digital contents.

\section{The Edulab Concept}

The project AGIRE is embedded into the Edulab concept and aims to promote the adoption of innovative teaching practices, seeking to respond to the knowledge and skills needs of the future generations and fostering the interaction between teacher and students as well as family involvement. This model is based on the premise that information technologies applied to Education allow the implementation of new models of teaching and learning, using multimedia digital contents and the support of elearning platforms for teaching and learning and a set of tools to create a new teaching generation. Thus the Edulab classrooms technology model (Figure 1) comprises: i) one teacher laptop; ii) tablets/laptops for students; iii) internet access points; iv) e-learning platforms; and v) educational resources provided by publishers - eBooks, and digital educational resources.

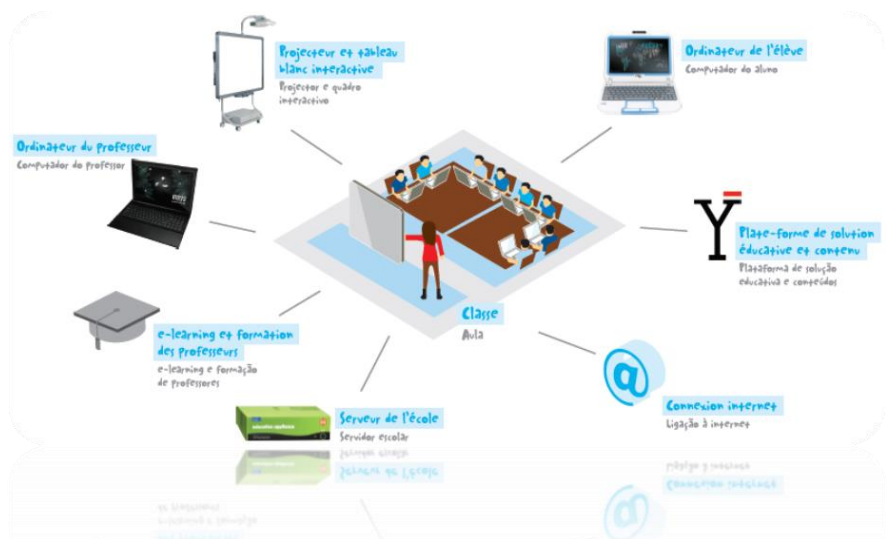

Figure 1. The Edulab Classrooms Technology Model (adapted from e-Xample, 2014)

The Edulab concept induces pedagogical innovation, such as collaborative work and flipped classrooms, by providing educational technology attractive to students as well as teacher training courses. Its main goals are: i) to improve the teaching and learning environment, by the integration of technology in educational context; ii) to increase the students' academic success and iii) to prepare students for their future employability. The Edulab network also promotes and supports the sharing of practices and experiences between schools that adopt the Edulab model at a national level. This network involves 10 school groupings, 20 schools and about 1000 students in Portugal.

\section{The AGIRE Project}

The AGIRE project, embedded in the Edulab concept, is a partnership between the University of Aveiro, the eXample consortium and the AEGN - "Agrupamento de Escolas da Gafanha da Nazaré", in the region of Aveiro (Portugal), with the financial support of QREN - "Quadro de Referência Estratégica Nacional" (ref. T377783477-00030493). 
The project is focused in promoting the following main dimensions: i) digital literacy of the actor (students, teachers and parents); ii) teachers training for the integration of Information and Communication Technologies (ICT) in educational contexts; iii) innovation of educational practices; iv) community involvement - parents; an V) digital contents. The goal of the project is to foster teachers' and students' digital literacy, by developing Teacher Training Courses (TTC) and taking advantage from the school technology environment (provided by the Edulab concept) on a pedagogical level. Two types of TTC are being implemented: i) a short-term 15 hours training focused on the technological aspects; and ii) a long-term 64 hours training focused on the pedagogical concepts for the integration of technology in classroom including practical exercises of the training strategies with students. An online community of practice was developed in order to support resources and experiences sharing within the tasks of the TTC. The project also aims to find and share 'best practices' on the Edulab in order to inspire other teachers/schools.

The AEGN Edulab includes the participation of 13 teachers and 5 classes from the three Basic Education Cycles, and a diversified set of disciplines (Math, Natural Sciences, History, Geography, English, French, Visual Education and Information and Communication Technology). Being in line with the Edulab model, the main technological resources in class, within the AEGN Edulab, include JP-inspiring knowledge tablets and laptops, B-bright interactive whiteboards, Leya teaching and learning platforms and Mythware e-learning software. The contribution of University of Aveiro to the project consists in two main strategic actions: i) monitoring the project (identifying contextual needs, monitoring educational innovation processes with the support of digital technologies and assess the pedagogical innovation outcomes); and ii) implementing a Teacher Training Course based on pedagogical principles in line with the Edulab concept. Thus, the University of Aveiro involvement focuses on three main domains, within a technologic context: i) educational practices, ii) digital literacy and iii) teacher training. Attending to the Edulab model described above and the educational technology and teacher professional development topics discussed, the AGIRE project stems from identified contextual needs and aims to monitor the project implementation within an interventional perspective, concerning educational innovation with the use of digital technologies. In the next section the explored methods are described and analyzed.

\section{Methods}

\section{Project Monitoring in Design-based Research Cycles}

A set of data collection instruments developed under this project allow its monitoring, as well as the redefinition of the TTC and its previewed activities. For example, a questionnaire on the trainee teachers' digital literacy, a grid to monitor the strategies implemented in class, as well as autonomous work task allowed each teacher to position its practice at the level of technology integration and to raise his/her expectations towards the educational technologies. Thus, the monitoring process comprises surveying the digital literacy of the different members of the educational community, classroom observations, observation mediated by e-platforms and document analysis. The aim of this methodology is to understand in depth the relationship between innovative educational practices, learning ecosystems enriched by technology, and the improvement digital literacy of the different participants as well as enhancement of student learning and their academic success, by the combination of the techniques and tools for collecting information mentioned before. The different data gathering tools and methodologies are described below.

\section{Questionnaire Survey}

In order to assess the initial representations of teachers of the AEGN on the integration of technology into their teaching practices, as well as their digital literacy, an online questionnaire survey was conducted at the beginning of the school year, which comprises the following dimensions: i) profile (age, gender, educational background, and years of teaching experience); ii) access to technological equipment (at home and at school); iii) degree of familiarity in performing various digital tasks; iv) how emerged the contact with technologies; v), what kind of activities involving the use of ICT in educational practice do teachers do; vi) perceptions about the use of ICT in school, from the point of view of student learning; vii) perceptions about barriers to the educational use of ICT. The results helped to identify the teacher's training needs and to define the structure of the TTC. 


\section{Classroom Observation}

Classroom observation occurred in two moments. Face-to-face observations were conducted in the end of the first school year in which the AGIRE project started (2013-14). Considering the 1st cycle of Basic Education (610 years old students), 5 classes were observed, on a 1st grade class, in which it was developed various activities with the student's personal laptops and using the Mythware ${ }^{\circledR}$ synchronization platform. For the 3rd cycle of Basic Education (11-15 years old students), two classes were observed (a 7th grade class in French discipline): i) a presentation of Leya on teaching and learning platform using tablets; and ii) the first lesson with tablets exploitation with the Leya digital book.

The second moment comprised classroom observations mediated by a platform, of classes conducted after the beginning of the long-term TTC. Thus, an online registration classroom grid was conceived and made available online, and filled by trainees (teachers of different disciplines and grades). A third moment is envisaged during to assess the exploitation of the pedagogical strategies being discussed during the TTC, presented in the following section.

\section{Teacher Training Course}

After attending a short-term (15 hours, from October $7^{\text {th }}$ to November $26^{\text {th }}$ ) technological TTC, a 64-hour TTC (from December $2^{\text {nd }}$ to June $2^{\text {nd }}$ ) involving 13 teachers of Basic Education (1st cycle of Basic Education - 6-10 years old, and 2nd and 3rd cycles of Basic Education - 11-15 years old) during the current school year is being conducted. The TTC, developed in a blended learning (bLearning) environment, follows the flipped classroom methodology comprising autonomous tasks for consulting multimedia resources at a distance and face-to-face sessions for discussion, reflection and collaborative work. Although blended learning has become somewhat of a buzzword in Education, there is still quite a bit of ambiguity about what it means (Graham, 2006). The different definitions of bLearning show us the diversity and strength of this type of learning. Generally, bLearning is defined as a combination of learning delivery methods, which include f2f instruction with asynchronous and/or synchronous computer technologies (Graham \& Robison, 2007) but the concept of blend can be interpreted in various ways. The literature highlights that when designing blended modes of teaching and learning, strategies and/or tools, we need to consider the teaching and learning context to obtain the most appropriate mix or blend. In this contribution, and since we think Graham's (2006) definition is the most accurate and widely accepted, bLearning is taken as the integration of f2f activities with technology-supported activities at a distance (Graham, 2006; Conole, Oliver, Falconer, Littlejohn \& Harvey, 2007). By practicing bLearning the conveniences of online courses are gained without the loss of f2f contact (Ginns \& Ellis, 2007). Thus, a learning environment is created which is richer than either a traditional f $2 f$ environment or a fully online environment (Harding, Kaczynski \& Wood, 2005).

The design of this TTC fits into a design-based methodology (Parker, 2011), allowing the analysis of the intervention outcomes and it's successively refinement towards a solution, following the phases: i) analyze the problem; ii) design and develop potential solutions; iii) implement and evaluate; and iv) reflect and report (Figure 2). Therefore it includes a sequence of planning cycle's strategies, of implementation and reflection, setting new interventions in real context (Carlos, Pombo \& Loureiro, 2014).

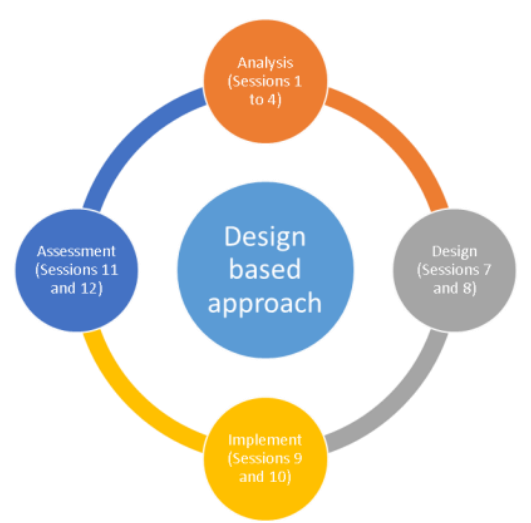

Figure 2. Training dynamics scheme following the design-based approach (Parker, 2011) 
The short-term TTC had several stages with training in technological components and training in a workshop environment, considering the components of the learning and classroom management platforms and all technologies available in the classroom. The long-term 64-hours TTC aims to develop innovative teaching and learning scenarios, changing teachers' practices and answering the following research questions: How can teachers develop and implement, in the classroom, practical activities with ICT? And how students can play an active role in carrying out those activities? Assuming the importance of the teachers' role in decision making concerning the use of ICT in classrooms, the key aims of this TTC are the following: i) implement a proper training environment for the integration of ICT in the classroom, conceiving practical activities to be undertaken with students; ii) monitor the implementation of practical activities with students in the classroom, with the use of ICT. In order to achieve those aims, the basic contents are defined to be developed under the TTC, that constitute the innovative learning scenarios mentioned above, such as: i) ICT and parenting involvement; ii) flipped classroom as a methodology for the evolution of quality of teaching scenarios and learning and for the improvement of school-family relationship; iii) collaborative work and collaborative learning on the evolution of the quality of teaching and learning scenarios; and iv) digital learning resources (Figure 3).

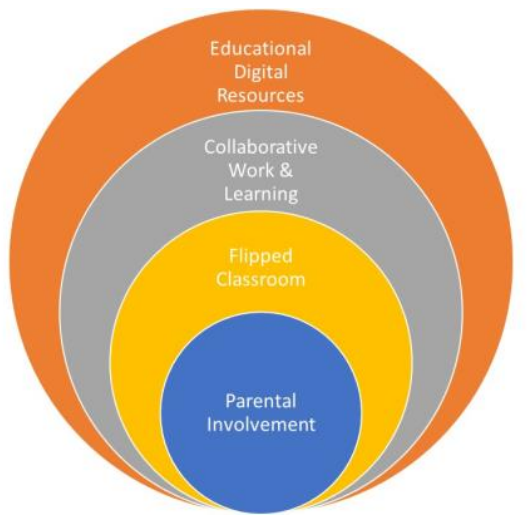

Figure 3. Teaching and learning innovative scenarios using ICT, in the long-term Teacher Training Courses (TTC)

The methodology of this TTC is both theoretical and practical and is conducted in bLearning. Thus it involves face-to-face sessions and at a distance autonomous tasks. During face to face sessions collaborative work situations are created in small groups of trainees and followed by discussions with the whole group, thus promoting the sharing of knowledge, experiences and resources created during the context of the TTC. An online platform is used in order to facilitate the communication and collaboration between trainers and trainees.

Moreover, the long-term TTC bLearning program implements itself the flipped classroom methodology, so that the trainees become familiar with this methodology to subsequently implement it with their students (Figure 4). This method, first introduced by Baker (2000), Lage, Platt \& Treglia (2000) is an active learning approach, where the transmissive teaching happens outside the classroom (using videos and online activities) and where the formal classroom time is used for students to undertake collaborative activities targeting the interaction (Strayer, 2012).

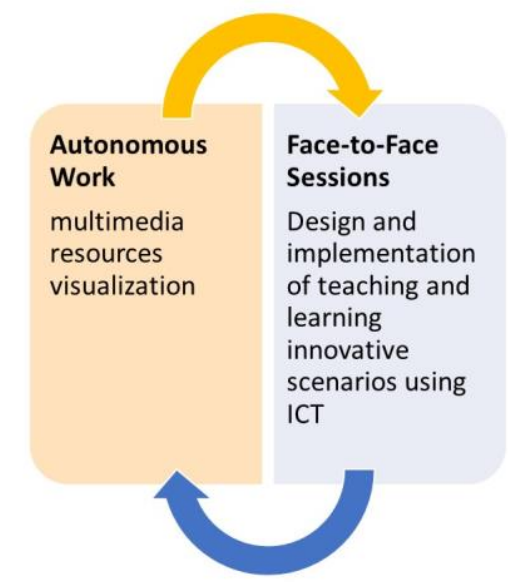

Figure 4. Flipped classroom methodology implemented in the bLearning TTC program 
Taking into consideration the implementation of the bLearning format, the first autonomous task included filling a questionnaire, based in the Technology Integration Matrix (TIM matrix - http://fcit.usf.edu/matrix/) an online multimedia assessment tool developed specifically by the Florida Department of Education to assess teacher's pedagogical technology integration in the classroom (Choy, Chen \& Bugarin, 2006; Ringstaff \& Kelley 2002). This instrument, based on a social constructivist theoretical framework, where learner's interactions are key constructs of learning, allows several applications, such as: i) "provides a framework for defining and evaluating technology integration"; ii) "sets a clear vision for effective teaching with technology"; iii) "gives teachers and administrators a common language for setting goals"; iv) "helps target professional development resources effectively" (http://fcit.usf.edu/matrix/). Therefore, it combines substantiated models of social constructivist theory (constructivist learning environments - active, collaborative, constructive, authentic and goal directed) (Jonassen et al., 2003), with the ACOT "Levels of Technology integration in the curriculum", that details the mentioned evolutionary process of technology integration on instructional practices, in 5 stages: entry, adoption, adaptation, appropriation and invention (Allsopp, Hohlfeld \& Kemker, 2007). In the mentioned questionnaire based on the TIM matrix, the trainees had thus to position their teaching practice considering the level of integration of technology in the curriculum, as well as the type of learning environment that the use of ICT helps to promote. Its results will be presented on the following topic, along with preliminary classroom observations and questionnaire survey.

\section{Results}

The main results and findings start from the identification of contextual needs in terms of the use of technology by teachers at the initial phase of the project, right after the first introduction of technology: laptop computers for students of three classrooms of the 1st cycle of Basic Education (6-10 years old) and tablets for students of two classes of the 2nd and 3rd cycles of Basic Education (11-15 years old), interactive whiteboards, eBooks, digital educational resources and an e-learning platform for classroom management. For the identification of those technical and pedagogical needs, some preliminary classroom observations were made along with a survey applied to teachers.

\section{Teacher's Representations from the Survey}

Considering teachers' agreement concerning the statement "My school is well equipped at the ICT point of view" (13 answers) (Figure 5) it is revealed a discrepancy between agreement and disagreement; while 4 teachers totally agreed, 6 agreed and 3 disagreed. We remind that those teachers are from 3 different schools (the 1st cycle school is a new school only with five years of existence, while the 2nd cycle school is old and the 3rd cycle was completely renewed and has now fairly good conditions) which may explain in parts the observed discrepancies.

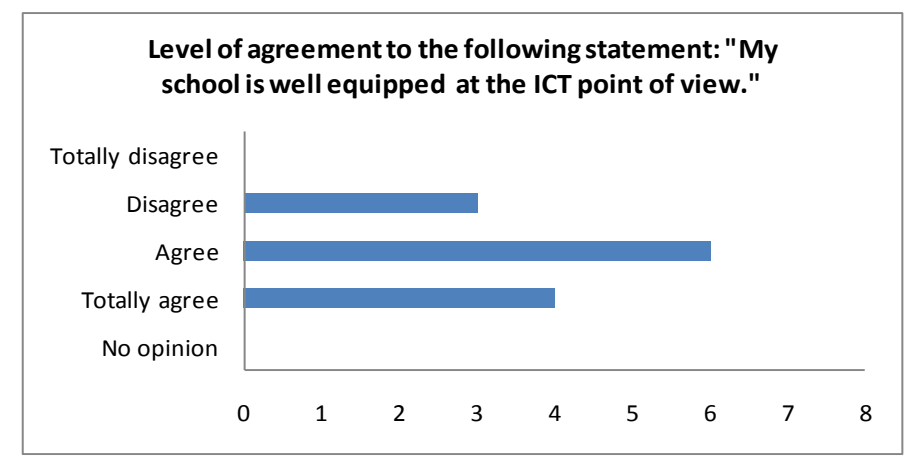

Figure 5. Level of agreement to the statement: "My school is well equipped at the ICT point of view."

In what concerns the statement "I use ICT very often to prepare my classes", all the teachers surveyed agree (4) or strongly agree (9) (Figure 6). 


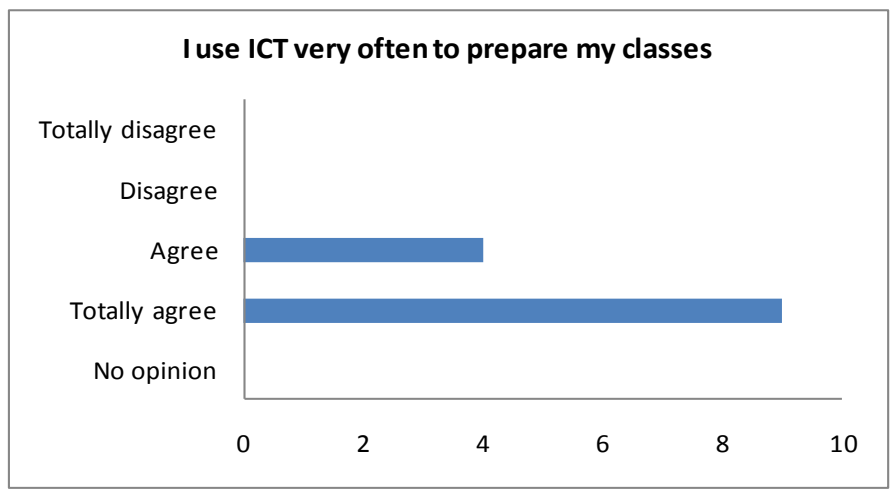

Figure 6. Level of agreement to the statement: "I use ICT very often to prepare my classes".

However, when asked about their usage of podcasts and/or video casts for educational purposes only one teacher agreed (Figure 7), and when asked about their familiarity in creating wikis to use with students (Figure 8), only one teachers answered "completely agree". Probably is the same teacher who is ICT teacher the only one who has facilities in using those kinds of tools to integrate them in classroom for education purposes.

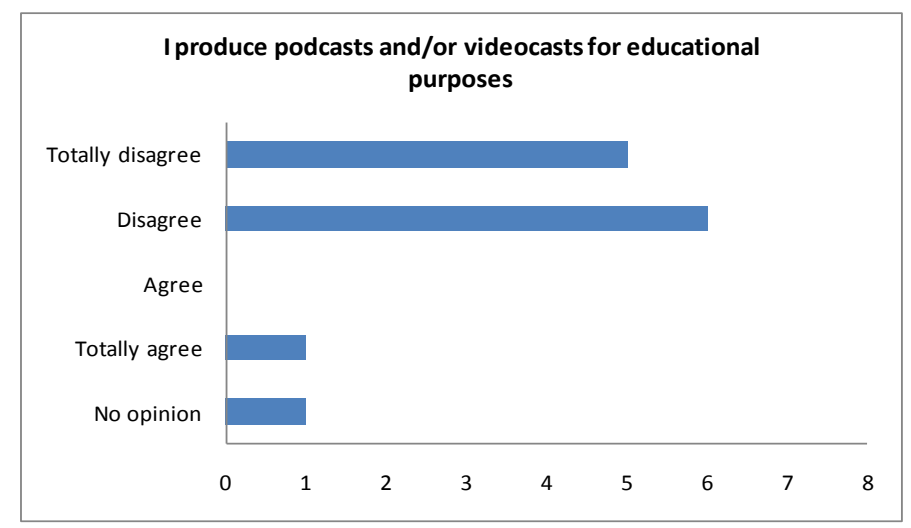

Figure 7. Level of agreement to the statement: "I produce podcasts and/or video casts for educational purposes."

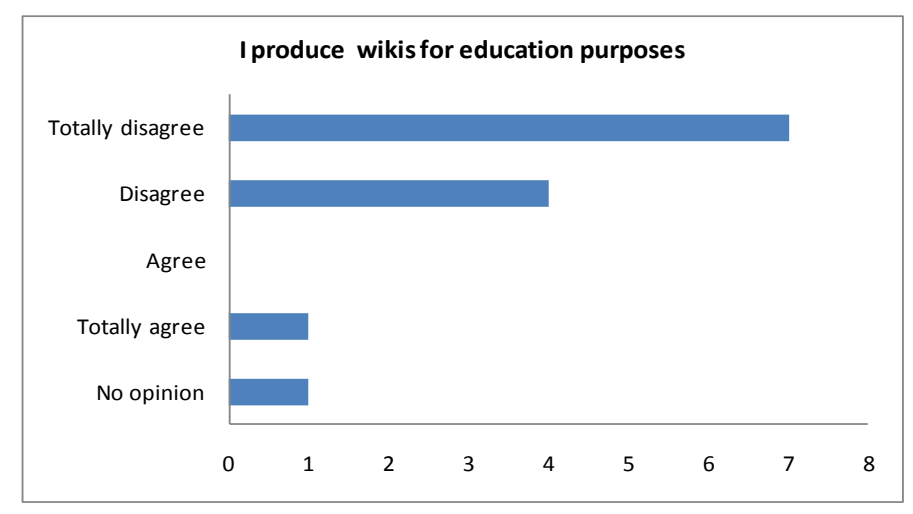

Figure 8. Level of agreement to the statement: "I produce wikis for educational purposes."

Those results helped us to design the long-term TTC focused on the pedagogical concepts for the integration of technology in classroom including practical exercises of the training strategies with students. Namely, we found important to include a face-to-face session to create videos for the flipped classroom methodology and other session to develop strategies and resources that promote collaborative work. As for the teachers' perceptions on the use of ICT in schools, in general, the teachers surveyed agree that the use of ICT in education contexts motivates or stimulates students for learning (5 agreed and 8 strongly agreed) (Figure 9), encourages collaborative work ( 7 agree and 5 strongly agree) (Figure 10), and promotes a student centered learning (5 agree and 6 strongly agree) (Figure 11), but that requires new skills for teacher (7 agree and 5 strongly agree) (Figure 12), being particularly significant in this last dimension, which reinforces the need of a long-term TTC. 


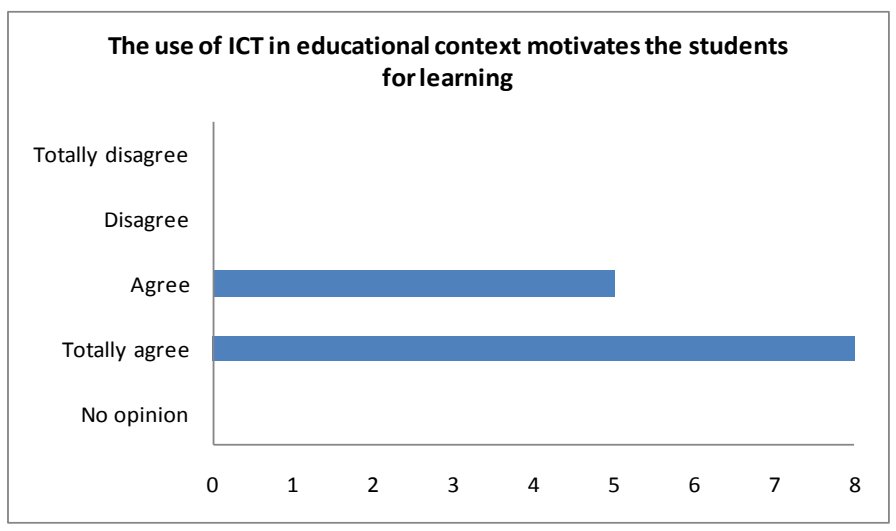

Figure 9. Level of agreement to the statement: "The use of ICT in educational context motivates the students for learning."

Teachers were asked about how they have learned how to use ICT in education and the results revealed the following: training courses (10), self-training (9), family support (7), colleagues support (6), initial training (2). Triangulating these results with those testifying that teachers are willing to learn more to innovate their practices, the best way to accomplish that would be a TTC that allows teachers to learn how integrate ICT and apply it in their practices at the same time. However, it was also observed that teaching practices still privilege a teacher centered environment in classrooms, and that the integration of ICT may enhance active learning, and may develop transversal skills, such as digital literacy, which is vital to prepare students for the future job market. Broadly, governments and education authorities emphasize the need for students to develop technology knowledge and skills (Cooper, Lockyer \& Brown, 2013).

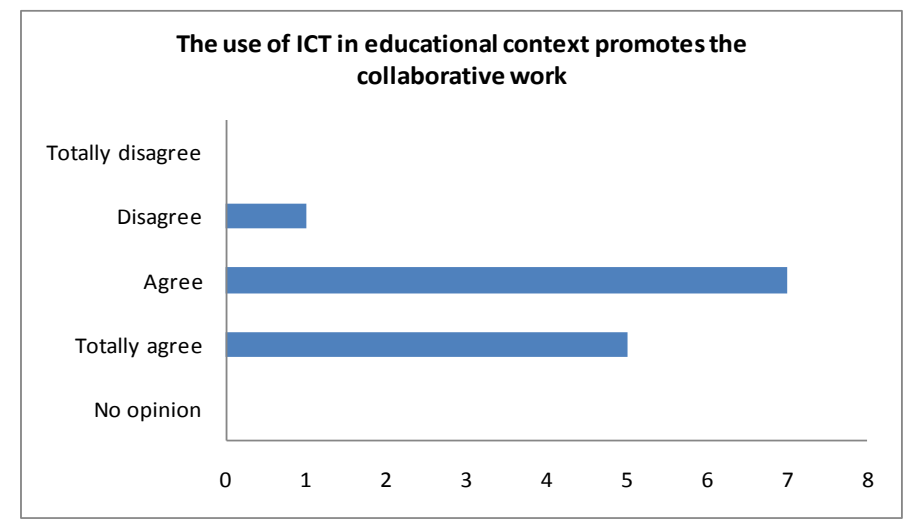

Figure 10. Level of agreement to the statement: "The use of ICT in educational context promotes the collaborative work."

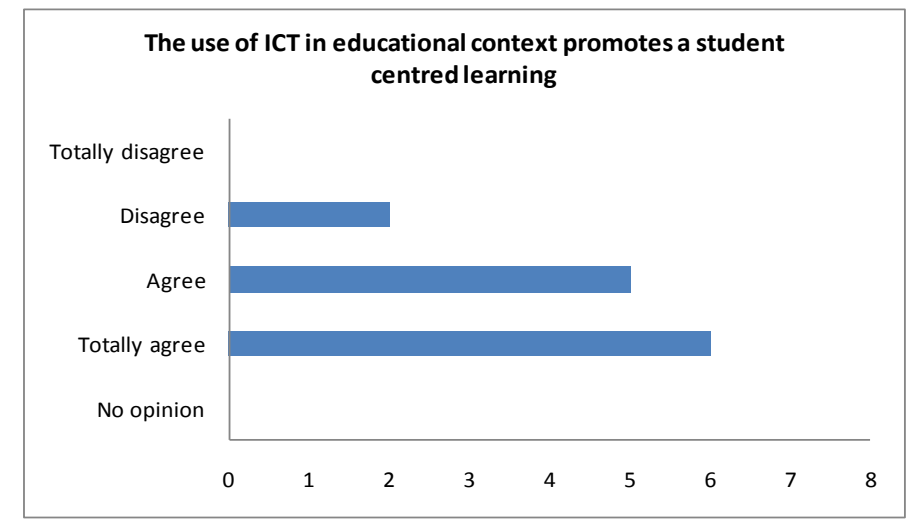

Figure 11. Level of agreement to the statement: "The use of ICT in educational context promotes a student centered learning." 


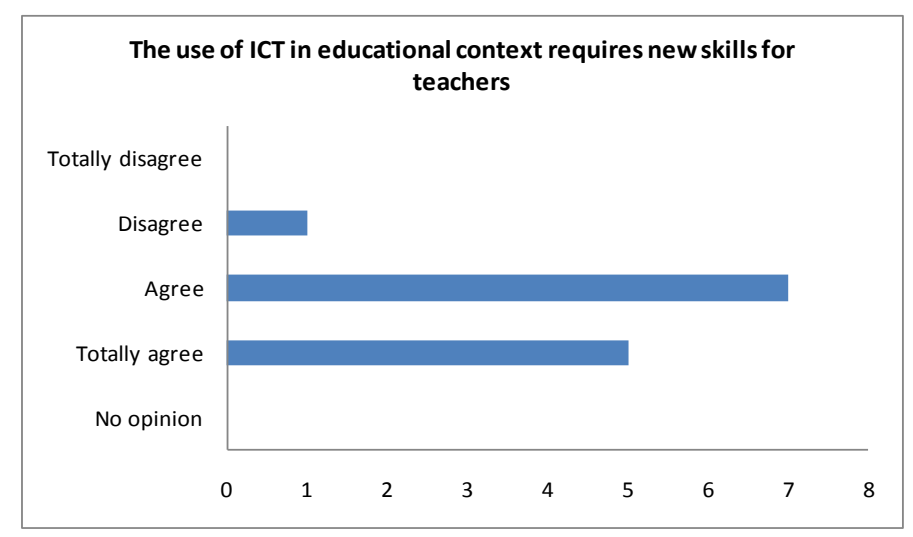

Figure 12. Level of agreement to the statement: "The use of ICT in educational requires new skills for teachers."

Concerning all that was expressed above we have data that support the pertinence of the TTC applied during the school year of the implementation of the project, where a set of technologies were available to those pilot classes. Additionally, monitoring the process is fundamental to evaluate what is doing well and what should be changed, in order to make decisions about how to integrate properly ICT in schools.

\section{Preliminary Classroom Observations}

In the 1st cycle of Basic Education five lessons in the 1st grade class were observed, where various activities were developed with the laptop computer and the e-learning platform for classroom management. In these activities it was always observed students enthusiasm and the initial tension of the teacher in the first activities was naturally decreased during the classes. Overall we found it was developed an active learning environment, encouraging the participation of students, but few constructive and still very focused on the teacher. In what concerns the level of integration of technology into the practices, and according to the classification of the Technology Integration Matrix - http://fcit.usf.edu/matrix/, it relays at the level of "adoption", although admittedly briefly switch to a level of "adaptation". Considering the natural climate of cooperation observed among students, we encourage the development of activities where collaboration can be encouraged.

For the 3rd cycle, it was observed two classes in the 7th grade class of French discipline. The first class comprised the presentation of the teaching and learning platform features on tablets and the other class corresponded to the first use of tablets, specifically using the e-book and the interactive whiteboard. The classroom management software Mythware was not used due to technical problems. We considered that the classroom was still very teacher-centered: the teacher followed the e-book and performs the multimedia activities available to it, requesting the participation of students. It was considered, in this class, that there has been an "adoption level" (according to the matrix referred above). To this observation adds some monotony in the final part of the class, and it is suggested the diversification of activities, in addition to the eBook.

\section{Monitoring the Process}

After the technological equipping of the Edulab, and after the preliminary observation classes and the survey applied to the teachers involved, it is important to monitor the process of technologies integration in the pilot classes. To accomplish that, the group of researchers of the AGIRE project developed a registration classroom grid to be filled by teachers in situations they had used technology on their classes and there were no observations programmed. That way it was possible to follow the process indirectly. The main results will be discussed below.

\section{Registration Classroom Grid}

Considering the list of resources that teachers were using, Table 1 shows that the most used ones were the tablet and the laptop (21 times used from 23 registrations) and then the eLearning software and the projector (14 and 13 times used, respectively, from 23 observations). EBook, worksheets, interactive whiteboard and videos were some other resources that teachers were using in their teaching practices. These results already show that 
teachers were using different resources that they were not used to use before the project, when they had not available such equipment or practice to use them.

Table 1. List of resources that have been used during the project school year (total number of registrations is 23 )

\begin{tabular}{lcc}
\hline Resources & number of times & $\%$ \\
\hline Tablet & 21 & 91 \\
Laptop & 21 & 91 \\
eLearning software (Mythware) & 14 & 61 \\
Projector & 13 & 57 \\
e-book & 9 & 40 \\
Worksheet & 7 & 30 \\
Interactive whiteboard & 5 & 22 \\
Video & 5 & 22 \\
\hline
\end{tabular}

According to the adopted strategies (Table 2) it is possible to note that teachers still give importance to application questions, like activities that students have to fill to prepare them for tests. In spite of formative assessment is valued in the Portuguese educational curriculum, the privileged way to assess students are still the tests along the school year. Individual work is still more selected than the collaborative one, the flipped classroom (strategy completely new for all the involved teachers) were also implemented in classrooms with good reply of students. Demonstration and experimentation were also other kind of strategies that find the potentialities of the tablet very useful for laboratory classes, as the tablet includes a lab camera working as a microscope.

Table 2. List of adopted strategies that have been used during the project school year (total number of registrations is 23 )

\begin{tabular}{lcc}
\hline Adopted strategies & number of times & $\%$ \\
\hline Application questions & 16 & 70 \\
Individual work & 12 & 52 \\
Oral exposition & 7 & 30 \\
Collaborative work & 7 & 30 \\
Flipped Classroom & 6 & 26 \\
Demonstration & 3 & 13 \\
Experimentation & 3 & 13 \\
Research & 3 & 13 \\
Debate & 2 & 9 \\
Other & 1 & 4 \\
\hline
\end{tabular}

Generally students did not have difficulties in using technologies and teachers are convinced that ICT could help them in what concerns: engagement, motivation, participation, development of digital skills, communication skills, problem solving skills, creativity and critical thinking, autonomous work, collaborative work and development of specific skills (disciplinary). In addition, concerning teacher's registrations, the use of ICT in their practices enhanced teachers' enthusiasm for teaching, their ability to motivate students, improved the dynamism of classroom activities and contributed to the development of teachers digital skills.

In addition, some registrations point out some benefits of using technology in class:

"The integration and the selection of the technology allowed "earning time" for other tasks (...) and the use of GeoGebra software allowed the teacher to previously draw the angles"

"The Mythware software proved to be a very effective tool to lesson objectives. The software allows students to control the time to solve problems and answer questions. The teacher has access to a list of students and she can see the progress of individual work. In addition, teacher has the access to the 'state of students': number of students who completed the activity and number of students who have sending it. The students were pleased and motivated with this form of assessment, mainly because they get an almost immediate feedback. Also for the teacher this was a facilitating tool especially concerning the correction process";

as well as some constraints were identified: 


\begin{abstract}
"As a first activity with the eLearning software (Mythware $\left.{ }^{\circledR}\right)$ there were some difficulties in using it, which slowed the rhythm of the class. After resolved technical issues and with regular use of the software seems to me that the rhythm and development of the classes can improve."
\end{abstract}

"Despite the motivation and commitment being high for the students, this type of work (group, with practical activities and technologies) makes the class noisier."

It's important to have a period of adaptation of new technology, as classes using technologies can be somehow motivating but also they can disturb the routine work of a classroom.

\title{
Monitoring the Process - Platform Observation during the Training Course
}

To monitor the process it was also used the platform of the TTC as an direct observation method of analysis, specially the autonomous work that teachers (trainees) are supposed to develop as autonomous tasks between the face-to-face sessions. The first challenge proposed to teachers was that they reflect into their own practices and evaluate their current and future (they intend to reach) integration of technology in their pedagogical practice, based on the Technological Integration (http://fcit.usf.edu/matrix/download/tim_table_of_teacher_indicators.pdf). The results of that activity can be seen in tables 3 and 4 .

Table 3. Evaluation of teacher's current integration of technology in their pedagogical practice, according to the Technological Integration Matrix

\begin{tabular}{|l|l|l|l|l|l|} 
& Entry & Adoption & Adaptation & Infusion & Transformation \\
\hline Active & $23 \%$ & $54 \%$ & $15 \%$ & $8 \%$ & $0 \%$ \\
\hline Collaborative & $8 \%$ & $77 \%$ & $15 \%$ & $0 \%$ & $0 \%$ \\
\hline Constructive & $0 \%$ & $92 \%$ & $8 \%$ & $0 \%$ & $0 \%$ \\
\hline Guthentic & $8 \%$ & $85 \%$ & $8 \%$ & $0 \%$ & $0 \%$ \\
\hline
\end{tabular}

Table 4. Evaluation of teachers future (they intend to reach) integration of technology in their pedagogical practice, according to the Technological Integration Matrix

\begin{tabular}{|l|l|l|l|l|l|} 
& Entry & Adoption & Adaptation & Infusion & Transformation \\
\hline Active & $0 \%$ & $8 \%$ & $8 \%$ & $54 \%$ & $31 \%$ \\
\hline Collaborative & $0 \%$ & $0 \%$ & $23 \%$ & $54 \%$ & $23 \%$ \\
\hline Constructive & $0 \%$ & $0 \%$ & $15 \%$ & $62 \%$ & $23 \%$ \\
\hline Authentic & $0 \%$ & $0 \%$ & $15 \%$ & $31 \%$ & $54 \%$ \\
\hline Goal-directed & $0 \%$ & $0 \%$ & $23 \%$ & $62 \%$ & $15 \%$ \\
\hline
\end{tabular}

According to the first autonomous work, teachers seems to be aware that they still are in a low level of integration of technologies, as they positioned mostly in the adoption level (Table 1), but they are willing to reach a higher level of integration and they seem to be whiling to reach the infusion level (Table 2). Considering the adoption level in a constructive way, the teacher provides some opportunities for students to use technology in conventional ways to build knowledge and experience. The students are constructing meaning about the relationships between prior knowledge and new learning, but the teacher is making the choices regarding technology use.

Considering the infusion level in a constructive way, that teachers inspire to reach, the teacher consistently allows students to select technology tools to use in building an understanding of a concept. The teacher provides a context in which technology is supportive of student autonomy in choosing the tools and when they can best 
be used to accomplish the desired outcomes. In a goal-directed way, the teacher creates a learning context in which students regularly use technology tools for planning, monitoring, evaluating learning activities and the teacher facilitates students' selection of technology tools.

This can be triangulated with teachers' citations they had as justifications of their choices.

"I want to have a deeper knowledge, to enrich and create moments of true passion for learning."

"In my opinion, the integration of technology in teaching and learning is very important and it is of obvious advantages, however I believe that this process can not only be controlled by the use of technology."

It's possible to note that teachers are completely motivated to integrate this pilot project in order to change things in their practices, but they are conscious that technology for itself is not sufficient, it has to be accompanied by pedagogical innovation that suits the technology itself and according to the learning aims and not according to the tools potentials.

\section{Conclusion}

The recognition of the potential of technologies in educational contexts has led the implementation of several initiatives involving programs to integrate ICT in teaching and learning. The Edulab concept intends to be a new educational model aiming at testing new technologies in terms of usability, effectiveness and transformative potential of the teaching and learning process. Its originality and innovative nature are different from similar projects once implemented because this model put the focus not only on the integration of technology in the classroom but also in the training and support of teachers and evaluation of its impacts on teaching and learning, optimizing the technologies and educational formats.

From previous national project results (for example, the "Minerva project", "Nónio-Século XXI" program and the "Mission Team on Computers, Networks and Internet at School"), it is not the technology itself that make the difference. Teachers may have the technology to use in classes but if they don't know how to use it properly, it is a waste of time and money. Given the results discussed above it is possible to conclude the relevance of conducting a TTC comprising two different modules: the first (and short) more technological and the second (and long-term) more pedagogical focused on the integration of ICT in the context of teaching and learning of various disciplines of the three cycles of Basic Education (students from 6 to 15 years old). With that TTC it was intended to develop new teaching skills, so that the limitations observed in the first classes of integration of technologies could be solved and that the teachers may have the competences needed to take advantage of that technology available from a pedagogical point of view. As Prensky (2005) mentioned, even if it is guaranteed access to technology in the classroom, this is not a sufficient condition for teachers to integrate into their teaching practice. It is necessary that teachers are willing to use it, putting technology at the service of an educational process with higher quality, which implies the adoption of teaching practices that fit this new model.

In addition, the project intends to encourage, by training teachers, the adoption of educational and performance formats with impact into their teaching practices using innovative strategies, such as the flipped classroom methodology and collaborative work. Taking this into account and according to the defined aims, this research was helpful to identify and characterize a set of teaching strategies developed using technology included in the Edulab. It was also observed that the available technologies, when optimized and accompanied by suitable teaching formats, can be very valuable in the whole process of teaching and learning, turning the classes more dynamic, effective and motivating, contributing to an active and significant learning. This is in accordance to Balanskat, Blamire \& Kefala (2006), and Jonassen (2007) that mention that the use of ICT cause a positive impact on the level of motivation and concentration contributing to positive effects on students behaviour and learning, turning it more active, meaningful and lasting.

\section{Monitoring the Process}

At this stage of the project, we highlight the gradual implementation of strategies that make use of technologies and the gradual diversification of technological resources. Importantly, training teachers and monitoring the process have had a central role, acting as the engines of the project. There are, however, some aspects that need 
to be improved, including the functioning of some technological features and equipment as well as student access to resources at home, a fact that destabilize the implementation of innovative teaching strategies.

As on the one hand, the monitoring instruments provide significant contributions to the training sessions of the course and, on the other hand, the autonomous work has also been used to monitor the process.

The results obtained so far allow us to state, although in a general way, that the use of technology, when used adequately and associated to strategies to meet the aims of the lessons, has a positive impact on the educational process. However, it is a process that requires time of maturation, because although teachers are apparently very motivated, there is still some resistance to the use of technology when it implies extra time to prepare the classes. The other constraint is that if technology does not work perfectly well, and some fails are detected, it can be a factor of discouragement for teachers.

\section{Future Work}

During the training course it is previewed peer observation of classes, which can be an innovation of this kind of projects, so that teachers can feel accompanied by their peers, sharing common problems, in order to increase the sense of belonging to a community, while promoting the spirit of mutual help, collaborative work and team spirit. It is also previewed the application of a questionnaire on students and their parents to have the view of all actors of the process (teachers, students and parents) to triangulate data, so that we may have a wider perspective of the project in order to make decisions to the next school year.

\section{Recommendations}

The project aims to find and share 'best practices' on the Edulab in order to inspire other teachers of other schools of different contexts. Through the collection and processing of data to support the outlined goals of the project, we hope to obtain a set of evidences that demonstrate the positive impact of teaching based on Edulab model, and from this develop a "model based on best practice" that can be a support to the implementation of these strategies by other teachers and other school clusters. It shall include the teaching strategies developed using technology used in the Edulab AEGN model, accompanied by educational formats and appropriate actions that may enhance the process of teaching and learning, making it more dynamic, effective and motivator, so that, it can provide support for the implementation of these strategies by other teachers and other schools.

\section{Acknowledgement}

This paper was developed under the AGIRE project; reference No T377783477-00030493, with financial support from the FEDER Structural Fund, specifically the POFC - Operational Programme of Competitiveness Factors, presented to the Incentive Scheme for Research and Development (SIIDT) of the QREN, AAC No. 08/SI/2012 - Project R\&D Companies in Co-promotion. The work will also have the support of CIDTFF, financed by FEDER funds through the Operational Programme for Competitiveness Factors - COMPETE and National Funds through the FCT - Foundation for Science and Technology under the PEstC/CED/UI0194/2011.

\section{References}

Allsopp, Hohlfeld \& Kemker (2007). The Technology Integration Matrix: The Development and Field-Test of an Internet Based Multi-media Assessment Tool for the Implementation of Instructional Technology in the Classroom. Florida Educational Research Association, Tampa.

Baker, J. W. (2000). The 'classroom flip': Using web course management tools to become the guide by the side. 11th International Conference on College Teaching and Learning, Jacksonville, Florida, United States, April 12-15.

Balanskat, A., Blamire, R., \& Kefala, S. (2006). The ICT Impact Report. A review of studies of ICT impact on schools in Europe. Retrieved from http://colccti.colfinder.org/sites/default/files/ict impact_report 0.pdf

Bergmann, J., \& Sams, A. (2012). Flip your classroom: reach every student in every class every day. Eugene, OR: International Society for Technology in Education 
Carlos, V., Pombo, L., \& Loureiro, M. J. (2014). Desenvolvimento profissional docente e comunidades online. Conceção de uma Oficina de Formação no Edulab do AEGN (projeto AGIRE). In G. L. Miranda, M. E. Monteiro, P. Brás (Orgs). Aprendizagem Online, Proceedings of the III International Congress of ICT in Education (TICEduca2014), (pp.734-741), Lisbon, 14 -16 November. Instituto de Educação da Universidade de Lisboa (ISBN: 978-989-8753-07-6). Retrieved from http://ticeduca2014.ie.ul.pt

Choy, P., Chen, X. \& Bugarin, R. (2006). Teacher professional development in 1999-2000: what teachers, principals, and district staff report (NCES 2006-305). Washington, DC, U.S. Department of Education, National Center for Education Statistics.

Conole, G., Oliver, M., Falconer, I., Littlejohn, A., \& Harvey, J. (2007). Designing for learning. In G. Conole \& M. Oliver (Eds). Contemporary perspectives in e-learning research: themes, methods and impact on practice (pp. 101-120). London: Routledge.

Cooper, N., Lockyer, L., \& Brown, I. (2013). Developing multiliteracies in a technology-mediated environment, Educational Media International, 50(2), 93-107.

Costa, A. L., \& Garmston, R.J. (2015). Check Your Gauges: Calibrating Conversations Assist Teachers in FineTuning Instruction. Journal of Staff Development, 36(1), 44-47.

Cox, M., Webb, M., Abbott, C. Blakeley, B., Beauchamp, T. \& Rhodes, V. (2004) ICT and pedagogy: A review of the research literature. A report to the DfES, BECTA. Retrieved from http://www.becta.org.uk/research.

Day, J., \& Foley, J. (2006). Evaluating a web lecture intervention in a human-computer interaction course. Education, IEEE Transactions on, 49(4)

e-xample (20149. Edulabs Desenvolvimento de Escolas para o futuro em Portugal. Retrieved from http://www.e-xample.com/

Ginns, P., \& Ellis, R., (2007). Quality in blended learning: Exploring the relationships between on-line and faceto-face teaching and learning. Internet and Higher Education, 10, 53-64.

Graham, C.R. (2006). Blended Learning systems: definition, current trends, and future directions. In C. J. Bonk, \& C. R. Graham (Eds.). Handbook of blended learning: global perspectives, local designs. San Francisco: Pfeiffer Publishing.

Graham, C.R., \& Robison, R. (2007). Realizing the transformational potential of blended learning: comparing cases of transforming blends and enhancing blends in higher education. In Blended Learning: Research Perspectives, edited by A.G. Picciano \& C.D. Dziuban, pp. 83-110. Needham, MA: Sloan Consortium.

Harding, A., Kaczynski, D., \& Wood, L. (2005). Evaluation of blended learning: analysis of qualitative data. Proceedings of the Symposium of Blended Learning in Science Teaching \& Learning (pp. 56-62). Parramatta, Australia: Australian Associate for Research in Education.

Horta, M. J. (2013). A formação de professores como percurso para o uso das TIC em actividades práticas pelos alunos na sala de aula. Instituto de Educação. Lisboa, Universidade de Lisboa. PhD thesis. Retrieved from http://hdl.handle.net/10451/8007

Jonassen, D. (2007). Computadores, Ferramentas Cognitivas. Porto: Porto Editora.

Lage, M. J., Platt, G. J., \& Treglia, M. (2000). Inverting the classroom: A gateway to creating an inclusive learning environment. Journal of Economic Education, 31(1), 30-43.

Monteiro, H., \& Loureıro, M. J. (2009). Práticas de utilização de computadores portáteis em contexto educativo: que impactos? Educação, Formação \& Tecnologias, 2 (1), 30-43. Retrieved from http://eft.educom.pt.

Paiva, J., Mendes, T., Canavarro, J., \& Pais, A. 2006. Experiências TIC na Escola: obstáculos à mudança. VIII Congresso Iberoamericano Informática Educativa. RIBIE 2006. Retrieved from http://www.ufrgs.br/niee/eventos/RIBIE/2006/ponencias/art089.pdf

Parker, J. (2011). A design-based research approach for creating effective online higher education courses, In 26th Annual Research Forum: Educational Possibilities (Western Australian Institute for Educational Research Inc), University of Notre Dame, Fremantle.

Prensky, M. (2005). Shaping Tech for the Classroom: 21st-century schools need 21st-century technology. Edutopia. Retrieved from http://www.edutopia.org/adopt-and-adapt

Ringstaff, C. \& Kelley, L. (2002). The learning return on our educational technology investment. Online report at: http://rtecexchange.edgateway.net/learningreturn.pdf.

Silva, P., \& Diogo, A. M. (2011). Usos do computador Magalhães entre a escola e a família: sobre a apropriação de uma política educativa em duas comunidades escolares. Ciências da Educação, 12, 9-48.

Sipila, K. (2010). The Impact of Laptop Provision on Teacher Attitudes towards ICT. Technology, Pedagogy and Education, 19(1), 3-16.

Strayer, J. F. (2012). How learning in an inverted classroom influences cooperation, innovation and task orientation. Learning Environments Research, 15(2), 171-193.

Yelland, N. (2006). Changing worlds and new curricula in the knowledge era. Educational Media International, 43(2), 121-131. 